\title{
Condition of Community Livelihood Assets Around Muhammadiyah's Charity Business Towards Sustainable Livelihoods During Covid 19 in Taliwang, West Sumbawa
}

\author{
Ibrahim \\ Geography Education Study Program, Faculty of Teacher Training and Education, Universitas Muhammadiyah \\ Mataram, Nusa Tenggara Barat, Indonesia
}

\section{ARTICLE INFO}

Article History:

Received: November 02, 2021

Revision: January 01, 2022

Accepted: January 07, 2022

Keywords:

Asset

Muhammadiyah Business

Charity

Covid-19

Corresponding Author

E-mail:

ibrahimali.geo@gmail.com

\begin{abstract}
Various covid-19 period programs have not made the community empowered and independent. The development of the Muhammadiyah Business Charity (AUM) program in the movement is still low in West Sumbawa Regency. Have various livelihood strategies in the surrounding community. This study aims to examine the condition of the livelihood assets of the community around AUM towards sustainable livelihoods during the Covid 19 period in Taliwang, West Sumbawa. The method used in this research is descriptive. The study results indicate that the community's livelihood assets around AUM are; first, human capital is more dominant in Lenang Late Village, reaching an average of 53.46; secondly, natural capital is more prevalent in Brang Bulu Hamlet, reaching an average of 2.58. The physical means of the three hamlets have the same average level going 18. Fourth, social capital is more dominant in Dusun Brang Pandan, reaching an average of 38.64; fifth, financial wealth is more prevalent in Dusun Lenang Late, reaching an average of 21.92. The level of community livelihoods at the Branch and Subdistrict levels during the Covid-19 period had various assets, but strategic measures were needed to ensure a better and sustainable livelihood.
\end{abstract}

\section{INTRODUCTION}

Poverty is a national problem with various approaches in handling it has not been able to get out of poverty. Various central and local governments are involved with multiple strategic programs to support the program. Major government programs with the Family Hope Program (PKH), the National Community Empowerment Program (PNPM), and social assistance programs. Various district government programs support the central government program, namely the Community-Based Total Sanitation Program (STBM).

To support poverty reduction programs in West Sumbawa Regency. Based on Regional Regulation No. 3 of 2016 concerning the Regional Mutual Assistance Empowerment Program (PDPGR). This regulation is implemented through the West Sumbawa Regent Regulation Number 19 of 2016 concerning PDPGR Implementation Guidelines. The birth of this regulation is the only cooperation program still valid in Indonesia.

In general, various PDPGR strategies can build togetherness and improve the welfare and economy of the local community through PDPGR activities. Still, their implementation is influenced by many factors such as communication, resources, disposition, and bureaucratic structure. PDPGR is not running optimally due to the absence of program socialization to the community, the low quality of PDPGR Empowerment agents as the spearhead of the program's success, and the lack of an Operational Structure Procedure (SOP) since 
2016, which has been used as a guide for program implementation (Lestanata et al., 2020).

In contrast to the religious approach taken by the Muhammadiyah association considering the history of the development and growth of Islam in Indonesia, Muhammadiyah is often referred to as a socio-religious renewal movement. The existence of Muhammadiyah plays an essential role in changing the socio-religious life in Indonesia. The existence of Muhammadiyah as a religious organization by constantly adhering to the commandments of ma'ruf nahi munkar has proven to have an active role in community empowerment in the fields of religion, education, health, economy, and other social activities.

The empowerment carried out by Persyarikatan Muhammadiyah to the community is only in the form of distributing food packages during the fasting month. The lasisMU scholarships given to students have not been thoroughly enjoyed by students. Only one student from the kokoda community has received the lasisMU scholarship, even though many students still need scholarships from the lasisMU (Edyanto, 2019).

West Sumbawa Regency is a district that has an active Muhammadiyah regional board with active management up to the branch and sub-branch level. Based on the report of the Muhammadiyah Regional Leadership (PWM) of West Nusa Tenggara (2018) in the realization of the 2018 work program, it turned out that the Community Empowerment Council (MPM) reached 0 percent. The low implementation of empowerment programs at the branch and branch level indeed results in the lower condition of the Muhammadiyah community.

Characteristics of the community around the Muhammadiyah Charity Business (AUM) in Seloto, West Sumbawa Regency, especially socio-economic conditions seen from the age aspect, the majority are still classified as productive age people reaching 39.19 percent, the highest number of family members reaches 71.01 percent in the category of fewer than four people, the number of family members of 47 people reached 23.19 percent, and above seven people the lowest was 5.80 percent. The highest education of the head of the family is Elementary School (SD), going 55.07 percent and not attending school, Junior High School, Senior High School, and bachelor's on average below 50 percent. The main occupation as a farmer is the highest at 68.12 percent, other jobs outside of farmers (fishers, entrepreneurs, employees, and civil servants) are still below 50 percent. The characteristics of the community around Muhammadiyah Charity are very diverse, especially related to socio-economic. These findings serve as the basis for policymaking in developing socio-economic-based programs for the community around the Muhammadiyah Charity Business, especially at the branch level (Ibrahim \& Mintasrihardi, 2020); and (Ibrahim et al., 2020).

Another statement of the economic empowerment strategy of Muhammadiyah's charity business is that it cannot be implemented following Muhammadiyah's charity business strategic plan. The program's implementation is still not optimal because the management is still focused on resolving conflicts at the internal level. Awareness from all regional administrators to the branch level in West Sumbawa Regency to resolve matters more wisely and develop better business charities in the future (Alil, 2019).

The low socio-economic characteristics of the community, especially during this Covid-19 period, require community livelihood assets to sustain the community's economy. Based on the identification of these problems with the low level of asset ownership in the community around the Muhammadiyah business charity, in this study, it is essential to examine the condition of the livelihood assets of the community around AUM towards sustainable 
livelihoods during the covid 19 period in Taliwang, West Sumbawa.

\section{RESEARCH METHODS}

This research is a type of quantitative research using a survey method. This research method aims to collect several data in the form of variables, units, or individuals simultaneously.
The study in this study used the micro-level. The research unit of analysis is the household represented by the Head of the Family $[\mathrm{KK}]$ as the respondent. Implementation of determining the sample of respondents using a proportional sampling technique.

Table 1. Number of villages, hamlets, and research samples

\begin{tabular}{ccccc}
\hline Regency & West Sumbawa & Total \\
\hline Districts & & Taliwang & 1 \\
Village & Seloto & 1 \\
Hamlet & 410 & Brang Pandang & Lenang Late & 3 \\
Number of RT / Dusun & $\mathbf{4 1}$ & 450 & 390 & 1040 \\
Number of RT Sampel Samples & $\mathbf{4 5}$ & $\mathbf{3 9}$ & $\mathbf{1 0 4}$ \\
\hline
\end{tabular}

Source: Secondary data analysis, 2020.

In detail, Table 1 shows that the population of each sample village was selected based on proportional sampling. Determination of the sample of household respondents using a model of 10 percent. The decision of 10 percent is due to the limited time in data collection.

The distribution of respondents at the study site is based on the number of household population times the number of household respondents, and the total population of households at the study site is distributed (Figure 1). The number of respondents in each research location was 104 respondents. The research method is described in the following flow chart.

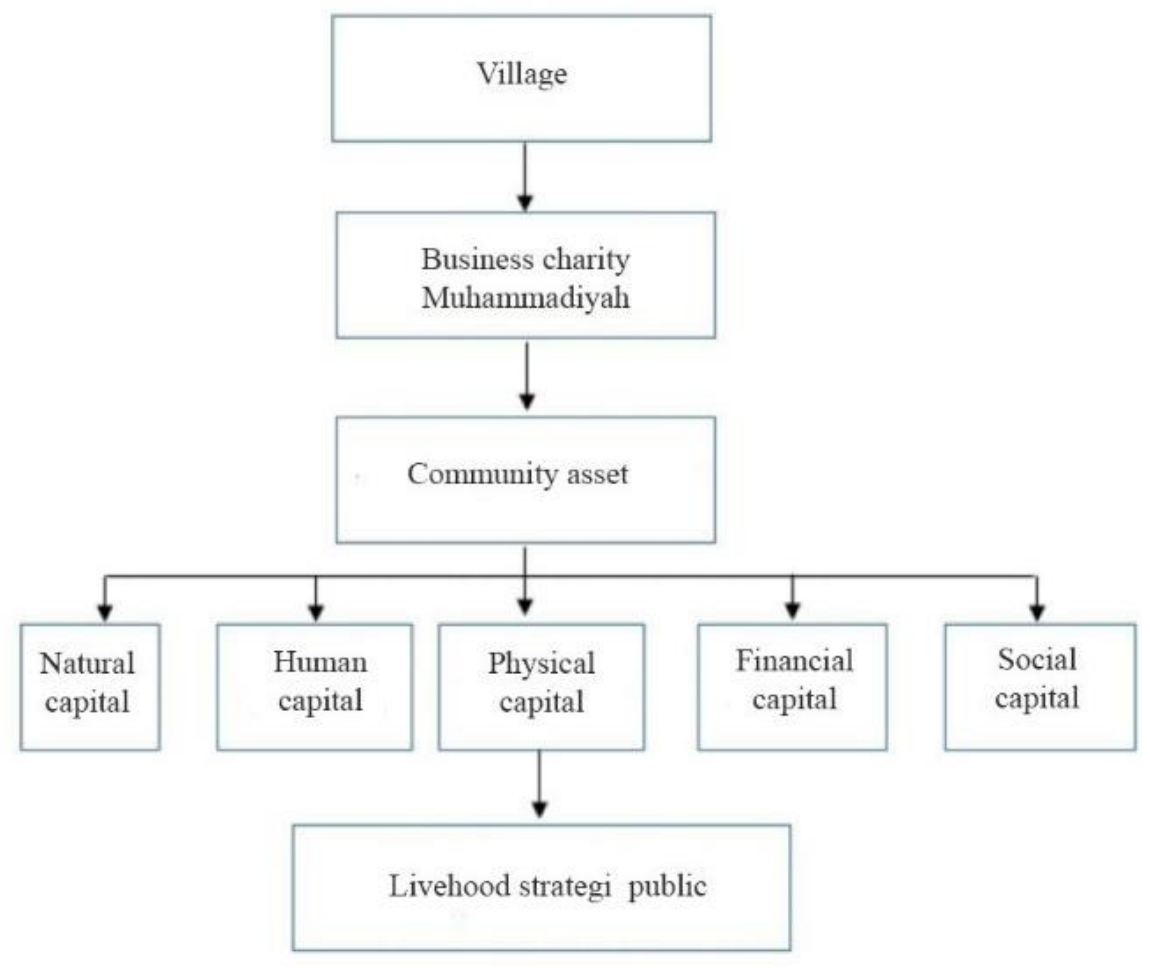

Figure 1. Research framework 
It is collecting data using observation, documentation, and questionnaires. The data analysis is a descriptive statistical analysis by calculating the average value.
Descriptive research is used to generate an overview of the data collected based on the respondents' answers by distributing items from each variable.
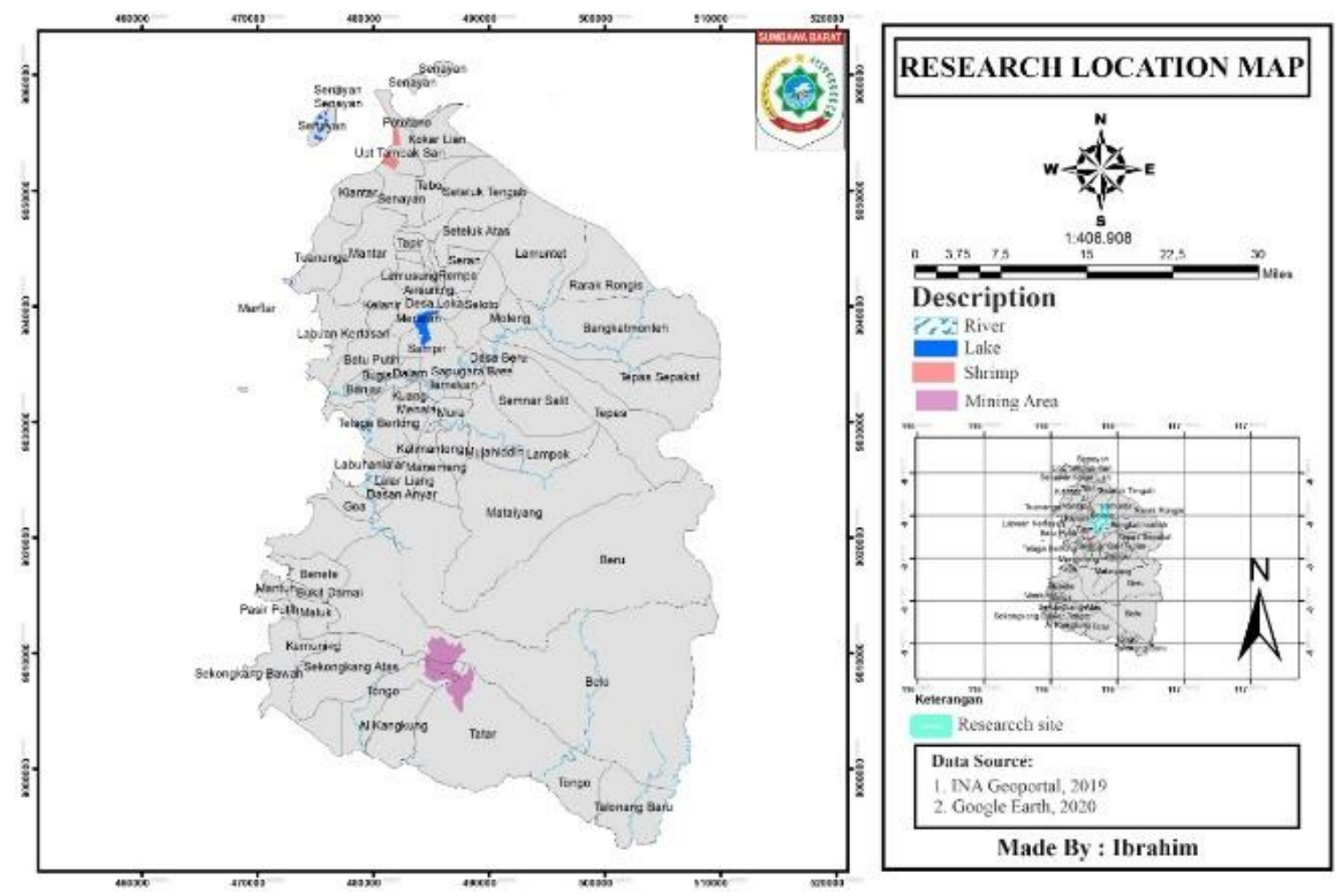

Figure 2. Research locations

\section{RESULTS AND DISCUSSION}

The availability of resources owned by the Muhammadiyah Charity Business community in rural areas as assets in a community varies from village to village. The characteristics of each community influence differences in the priority of resource availability.

Livelihood assets of the community around AUM in each hamlet in Seloto Village, Taliwang District, West Sumbawa
Regency vary, depending on the value of the capital owned by the community. The variations of community livelihood assets, namely human capital (human capital), natural capital (natural capital), social capital (social capital), financial capital (financial capital), and physical capital (physical capital). The interrelationships of all these variables among the components of livelihood resources are detailed in Table 1 below.

Table 1. Livelihood assets of seloto taliwang village

\begin{tabular}{lccc}
\hline \multirow{2}{*}{ Capital } & \multicolumn{3}{c}{ Value Scale/ Hamlet } \\
\cline { 2 - 4 } & Lenang late & Brang Pandan & Brang Bulu \\
\hline Human & 53.46 & 52.77 & 52.9 \\
Natural & 2.31 & 2.37 & 2.58 \\
Physique & 18 & 18 & 18 \\
Social & 38.46 & 38.64 & 38.63 \\
Financial & 21.92 & 21.87 & 21.66 \\
Amount & 134.15 & 133.65 & 133.77 \\
\hline
\end{tabular}

Source: Primary data processing, 2020. 
The results of data processing (Table 1) measurement of community assets around Amal Usaha Muhammadiyah illustrate community assets. This is done because the condition of the community around the Muhammadiyah Charity Business culturally and in rural areas have the same background. However, this condition will be different in controlling natural resources owned. The distribution of livelihood assets for Seloto Village, Taliwang District, in detail is as follows.

\section{Human Capital}

Livelihood assets of the community around the Amal Usaha Muhammadiyah vary. The level of value of each capital owned by each community (Table 1). Human capital is essential in supporting sustainable livelihoods during the COVID-
19 period-education as an investment in human capital. Education is social capital because a person will get all social resources such as networks, beliefs, values, and norms with schooling. The more a person attends formal or informal education, the more social networks he gets. Social capital, education as well as cultural capital and symbolic capital (Suhaeni, 2019).

Human capital in this study is the value of the variables of education, health, experience, knowledge or skills, workforce, and self-character/motivation/innovation. Human quality needs to be continuously improved, considering that increasing Human Resources is an asset in selfdevelopment. Human capital at the research location has a level of human capital that has an average level of not too far away. Human Capital is detailed in Figure 3 below.

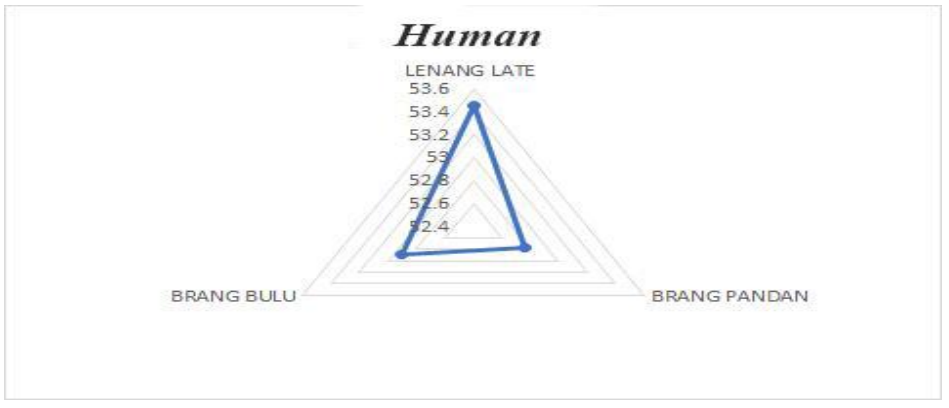

Figure 3. Human capital

Based on Table 1 and Figure 3, the highest human capital value is in Dusun Lenang Late, reaching 53.56, and the lowest is in Dusun Brang Pandan, running 52.77. The level of human capital measured by the level of education owned by the community around the Muhammadiyah Charity Business is still low.

The low socio-economic level of the community around AUM in West Sumbawa include: 1) the age of the community is more dominant in productive age reaching 39.19 percent, 2) the highest number of family members reaches 71.01 percent in the category of fewer than four people, 3 ) the highest education of the head of the family is Elementary School (SD) reached 55.07 percent and 4) the highest occupation as a farmer reached 68.12 percent. The characteristics of this diverse community require appropriate program steps to support the AUM program based on local wisdom to directly impact rural communities (Ibrahim \& Mintasrihardi, 2020).

This statement is reinforced by the HR development strategy of agro-industry stakeholders by increasing productivity to achieve prosperity and sustainability. The HR development strategy is a strategic action to give birth to the competence and quality of agro-industry players with high competitiveness, especially in facing global competition and competition in the MEA region through various $H R$ capacity development programs. HR investment is an intelligent investment that has an essential meaning for regional development and 
improving people's welfare (Fadhil et al., 2017); (Sulastriyono \& Saputra, 2020); and (Ibrahim, 2020).

\section{Natural Capital}

Natural capital is broadly a resource that can generate benefits in the future. Natural capital is closely connected with the primary meaning in the daily life of the people around AUM. Especially in this Covid-19 period, with the limited space for people to move, it will weaken the economic level of the community. Natural capital sourced from agricultural products will compete and meet primary needs.

Farming is a business that depends on natural conditions, especially on the environment, climate, and policies that change all the time. Unfortunately, these social and ecological changes occur more rapidly, so rural farming households are often faced with uncertainties that can lead to vulnerability. These uncertainties can be caused by anthropogenic factors or natural factors such as natural disasters and nonanthropogenic factors, namely factors outside of natural elements such as humans, price fluctuations, and government policies. (Nisa, 2016).

Natural or environmental capital has a relationship with agricultural production factors as the primary source of income in rural areas. Natural capital has a level of natural capital with a similar level, and the level of inequality is not too far off. The story of natural capital is detailed in Figure 4 below.

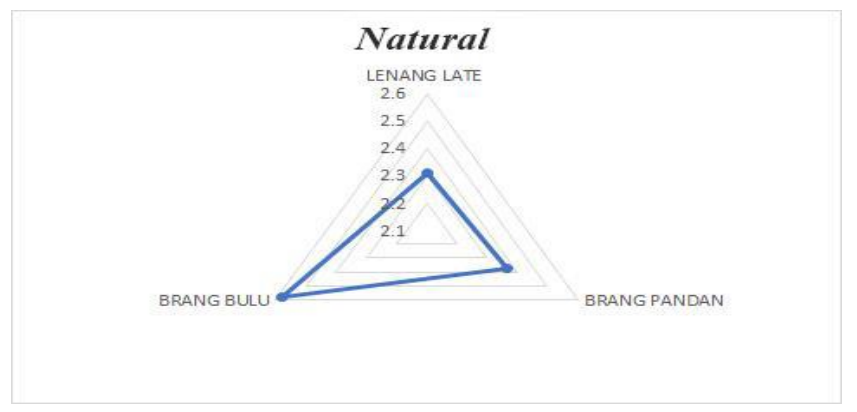

Figure 4. Natural capital

Observing Table 1 and Figure 4, the highest natural capital value is in Dusun Brang Bulu, reaching 2.58, and the lowest is in Dusun Lenang Late, reaching 2.31. The level of natural capital is measured by the ownership of agricultural land owned by the community around the Muhammadiyah Business Amal in meeting sustainability needs during the Covid-19 period. Considering the dominant occupation in the community around AUM in Seloto Village, the lowest work characteristics are civil servants, as much as 6 or 8.70 percent, and the highest is 47 people or 68.12 percent. This condition is due to the high dependence of rural communities as farmers (Ibrahim \& Mintasrihardi, 2020), (Yahya \& Yahya, 2020), and (Mergel, 2012).

Various efforts to increase natural capital are carried out to increase community productivity. The main strategies needed to secure increased production of staple food commodities are (i) adaptation to climate anomalies; (ii) construction and rehabilitation of irrigation networks and farm roads; (iii) printing of new paddy fields; (iv) supply of superior quality seeds and fertilizers effectively; (v) prudent import policies so as not to harm producer farmers in Indonesia; (vi) increasing the role of Bulog in absorbing domestic production and stabilizing grain/rice prices; (vii) increasing the role of Autonomous Regions in the food supply; and (viii) reduction of rice consumption per capita (Hadi \& Susilowati, 2010)

\section{Physical Capital}

Physical capital was an essential asset in supporting people's livelihoods during 
the Covid-19 period. Physical capital relates to basic facilities and infrastructure built to support the community's livelihood processes. The existence of infrastructure as a supporter in carrying out community activities to keep the economy in the current limited period. In detail, physical capital includes facilities and infrastructure, work/production equipment, and technology.

A strategy to support the community's physical capital sustainably during the
Covid-19 period. Even longer, residents tend to be more dependent on the nonagricultural sector. But the basis of their livelihood is as a farmer. Social transformation where the value of agriculture to society has decreased (Fridayanti \& Dharmawan, 2015).

Physical capital has a degree of similarity and does not have gaps between hamlets. The distribution of natural wealth is detailed in Figure 5 below.

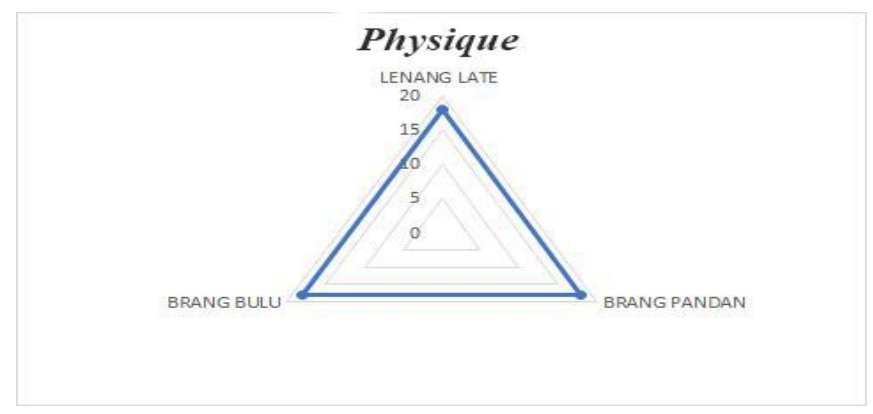

Figure 5. Physical capital

We observe in Table 1 and Figure 5 that the value of physical capital in Dusun Brang Bulu, Brang Pandan, and Lenang Late both have an average value of 18 . The level of physical capital is measured based on access to education, health and economic facilities, access owned by the community around the Muhammadiyah Business Charity in meeting sustainability needs during the Covid-19 period. The existence of these assets is vital as a support for daily activities.

Rural community activities around Muhammadiyah charities with various activities owned but still have low access. Moreover, rural communities are synonymous with agriculture. In this case, cooperatives and Gapoktan, the strengthening of semi-formal organics need to be increased, especially in the number of credits disbursed for organic rice farming. To reach more other organic rice farmers who have not received praise. Implement organic channeling so that recognition from formal organic and government can be absorbed and utilized for financing organic rice farming but still with the ease of the process that has been implemented (Wati, 2015).

Most of the rural poor have socioeconomic characteristics as farmers. Strengthening farmer groups is needed to improve the welfare of farmers. Although many farmer group institutions have been formed, it isn't easy to find active farmer groups, and farmer groups use these institutions to improve performance to improve farmers' welfare. At the same time, farmer groups have a significant role and function in driving agricultural development efforts.

Institutional strengthening is carried out through several efforts, including encouraging and guiding farmers to be able to cooperate in the economic field in groups, growing through increasing assistance facilities and access to capital and increasing efficiency and effectiveness of farmers, as well as increasing the capacity of farmers' human resources through various assistance and training, for administrators and members. Technically, field agricultural extension workers carry out efforts to increase farmer groups in empowerment 
(PPL). Assistance in the development of farmer groups is carried out by NGOs and other organizations that are considered capable of being involved in efforts to strengthen farmer groups in empowerment (Ramdhani et al., 2015); (Xu et al., 2019); (Choden et al., 2020); dan (Guo et al., 2019).

\section{Social Capital}

Social capital owned by the community is well developed, such as village organizations, beliefs, norms, and networks. To realize an independent village, of course, facing social challenges, namely jealousy between hamlets related to the assistance funds provided and the emergence of economic actors around the town. (Sidik, 2015).

Social conditions in the village community are still good. The existence of cooperation is still being implemented in this area. Farmers' social capital can be divided into 3, namely: organization, community service, and routine activities. Social capital is significant in a survival strategy during the Covid-19 period around AUM. Social capital in the community is still substantial in that the research locations have a level of similarity and the level of disparity between hamlets is not too far away. The distribution of social capital is detailed in Figure 6 below.

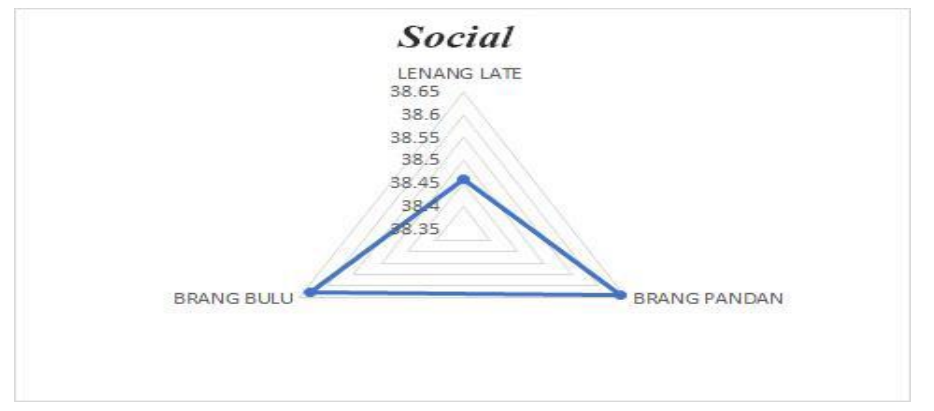

Figure 6. Social capital

Observing Table 1 and Figure 46explains that the highest natural capital value is in Brang Pandan Hamlet, reaching 38.64, and the lowest is in Lenang Late Hamlet, arriving at 38.46. Social capital is measured based on elements of community organization in the community, participation, cooperation, kinship, and social networks.

The community's high level of social capital is due to the high level of participation in group activities, a sense of tolerance, reciprocity, and a heightened sense of trust among members. The system of values and norms, the existence of cooperation, and the direction of their cooperation network support the group's existence-aspects of social capital (social capital) relationship with the group's presence. Good social capital is maintained continuously and recognized by the wider community, and group achievements tend to be easy to achieve. (Putri \& Hidayat, 2011).

During the Covid period, agricultural land's limitations in managing agricultural products can use social capital as an alternative-social capital of small land farmers in fulfilling household livelihoods. Small land farmers take advantage of their social capital. Small-land rice farmers can run other income alternatives outside of farming activities by reducing the difficulty of living to fulfill household livelihoods. Various alternative incomes for farmers to achieve household livelihoods by utilizing their social capital such as raising livestock, taking debt, and working together on agricultural land (Rahmadi \& Santoso, 2016), (Schwitter, 2020), and (Djaha et al., 2018).

\section{Financial Capital}

Financial capital as a community livelihood asset during the Covid-19 period. 
This financial capital relates to financial resources that can be used and utilized by the community in achieving livelihood goals. The low level of public access to capital, especially financial capital, is the cause of poverty. Limited access to financial capital causes a tiny group of selfdevelopment. Social capital has an essential role as a livelihood strategy for poor households and can be one of the main concerns in developing sustainable livelihood strategies (Widodo, 2011).

Financial capital in rural communities still has strong family values. At the research location, the level of economic capital similarity between hamlets is not too far away. The distribution of financial capital in detail is shown in Figure 7 below.

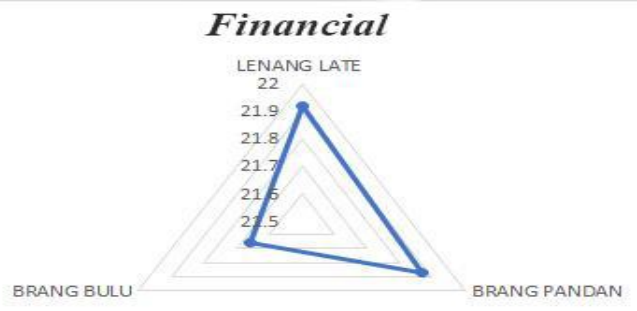

Figure 7. Financial capital

Observing Table 1 and Figure 7 explains that the highest value of financial capital is in Dusun Lenang Late, reaching 21.92, and the lowest is in Dusun Brang Bulu, arriving at 21.66. Financial wealth is measured based on the cumulative value of savings, assets owned, and the importance of grants. The distribution in the three hamlets has the same average level of significance. During the Covid-19 period, there were no different patterns of financial approach in overcoming the sustainability of their livelihoods.

The community's low income during the Covid-19 period is very much felt. The economy of the lower middle class is the part that feels the most painful beating during this pandemic. The direct impact is not only the death of the coronavirus itself, but the death of poverty and hunger due to many not getting any more income, losing their jobs, and the collapse of the businesses they have built (Nurdin, 2020), (Bonoli et al., 2019) dan (Gupta et al., 2016).

This statement is reinforced by the existence of Micro Waqf Banks playing a role in the COVID-19 pandemic situation carrying out a new system including the process of collecting data on customers affected by the COVID-19 pandemic, facilitating installments, providing facilities for utilizing online media as business development, closing the financing process but providing facilities to be directed to customers. other financial institutions (Nugrahana \& Zaki, 2020).

\section{CONCLUSION}

The condition of the livelihood assets of the community around Muhammadiyah's business charity towards sustainable livelihoods during the covid 19 period in Taliwang, West Sumbawa Regency was; first, human capital was more dominant in Lenang Late Hamlet reaching an average of 53.46, second, natural capital was more prevalent in Brang Bulu Hamlet going an average of 2.58, Third, the physical means of the three hamlets have the same average level of 18 , fourth, social capital is more dominant in Brang Pandan Hamlet reaching an average of 38.64 , fifth, financial wealth is more prevalent in Lenang Hamlet Late earned an average of 21.92. The condition of the community's assets around AUM in supporting sustainable livelihoods during the COVID-19 period is diverse, so a fast, strategic, and sustainable empowerment model is needed. This empowerment is an alternative in developing a model of 
community empowerment for branches and branches during the Covid-19 period.

\section{ACKNOWLEDGEMENTS}

The Research Grant funded Batch 4 of the PP Muhammadiyah Diktilitbang Council. Thank you to all parties, especially the NTB Regional Management, Branch and Branch Managers in Sumbawa Barata, and those who have supported this research.

\section{REFERENCES LIST}

Alil, I. (2019). Strategi Pemberdayaan Ekonomi Melalui Program Amal Usaha Muhammadiyah Pada Perdesaan Di Sumbawa Baratstrategi Pemberdayaan Ekonomi Melalui Program Amal Usaha Muhammadiyah Pada Perdesaan Di Sumbawa Barat. Jpek (Jurnal Pendidikan Ekonomi Dan Kewirausahaan). Https://Doi.Org/10.29408/Jpek.V3i2 .1712

Bonoli, A., Zanni, S., \& Awere, E. (2019). Organic Waste Composting And Sustainability In Low-Income Communities In Palestine: Lessons From A Pilot Project In The Village Of Al Jalameh, Jenin. International Journal Of Recycling of Organic Waste In Agriculture, 8(3), 253-262. Https://Doi.Org/10.1007/S40093019-0264-8

Choden, K., Keenan, R. J., \& Nitschke, C. R. (2020). An Approach For Assessing Adaptive Capacity To Climate Change In Resource Dependent Communities In The Nikachu Watershed, Bhutan. Ecological Indicators, 114. Https://Doi.Org/10.1016/J.Ecolind.2 020.106293

Djaha, A. S. A., Lino, M. M., \& Mau, A. E. (2018). Social Capital Making Through Local Institution: A Village Community Empowerment Strategy In The Pulau Buaya Village, East Nusa Tenggara Of Indonesia. Russian Journal Of Agricultural And Socio-Economic Sciences, $\quad 77(5)$, 116-122.
Https:/ / Doi.Org/10.18551/Rjoas.201 $8-05.14$

Edyanto, K. (2019). Peran Muhammadiyah Dalam Pemberdayaan Masyarakat Kokoda Di Kota Sorong. Jurnal Noken: Ilmu-Ilmu Sosial. Https://Doi.Org/10.33506/Jn.V4i1.36 0

Fadhil, R., Maarif, M. S., Bantacut, T., \& Hermawan, A. (2017). Model Strategi Pengembangan Sumber Daya Manusia Agroindustri Kopi Gayo Dalam Menghadapi Masyarakat Ekonomi Asean. Jurnal Manajemen Teknologi.

Https:/ / Doi.Org/10.12695/Jmt.2017. 16.2.3

Fridayanti, N., \& Dharmawan, A. H. (2015). Analisis Struktur Dan Strategi Nafkah Rumahtangga Petani Sekitar Kawasan Hutan Konservasi Di Desa Cipeuteuy, Kabupaten Sukabumi. Sodality: Jurnal Sosiologi Pedesaan. Https://Doi.Org/10.22500/Sodality. V1i1.9388

Guo, S. Li, Li, C. Jie, Wei, Y. Li, Zhou, K., Liu, S. Quan, Xu, D. De, \& Li, Q. Yu. (2019). Impact Of Land Expropriation On Farmers' Livelihoods In The Mountainous And Hilly Regions Of Sichuan, China. Journal of Mountain Science, 16(11), 2484-2501. Https://Doi.Org/10.1007/S11629018-5017-Z

Gupta, V., Downs, S. M., Ghosh-Jerath, S., Lock, K., \& Singh, A. (2016). Unhealthy Fat In Street And Snack Foods In LowSocioeconomic Settings In India: A Case Study Of The Food Environments Of Rural Villages And An Urban Slum. Journal of Nutrition Education And Behavior, 48(4), 269-279.E1. Https://Doi.Org/10.1016/J.Jneb.2015 .11 .006

Hadi, P. U., \& Susilowati, S. H. (2010). Prospek, Masalah Dan Strategi Pemenuhan Kebutuhan Pangan Pokok. Bio-Energy And Climate Change. Ibrahim. (2020). Productivity The Village Owned Enterprises To Improve The 
Economic Community Of Gold Mining Areas In Sumbawa Island, Indonesia. International Journal of Scientific And Technology Research.

Ibrahim, I., \& Mintasrihardi, M. (2020). Karakteristik Sosial Ekonomi Masyarakat Sekitar Amal Usaha Muhammadiyah Di Sumbawa Barat. Jurnal Geografi. Https://Doi.Org/10.24114/Jg.V12i02. 17734

Ibrahim, I., Mintasrihardi, M., Mas'ad, M., Herianto, A., Junaidi Am, J. A., \& Kamaluddin, K. (2020). Strategi Penghidupan Berkelanjutan Masyarakat Sekitar Amal Usaha Muhammadiyah Pada Masa Covid 19 Di Taliwang Sumbawa Barat. Justek: Jurnal Sains Dan Teknologi, 3(2), 46. Https://Doi.Org/10.31764/Justek.V3 i2.3539

Lestanata, Y., Zitri, I., \& Susiana, S. (2020). Strategi Pemerintah Dalam Pelaksanaan Program Daerah Pemberdayaan Gotong Royong Di Desa Kelanir Kecamatan Seteluk Kabupaten Sumbawa Barat Tahun 2017. Jiap (Jurnal Ilmu Administrasi Publik).

Https://Doi.Org/10.31764/Jiap.V8i2. 2764

Mergel, I. (2012). Open collaboration In Public Sector: The Case Of Social Coding On Github. Government Information Quarterly, 1(1), 1-10.

Nisa, L. K. (2016). Pengaruh Livelihood Assets Terhadap Tingkat Resiliensi Nafkah Rumahtangga Petani. Studi Pustaka.

Nugrahana, Y. R. Y., \& Zaki, I. (2020). Peran Bank Wakaf Mikro Di Masa Pandemi Covid-19. Jurnal Ekonomi Syariah Teori Dan Terapan. Https:/ /Doi.Org/10.20473/Vol7iss20 209pp1731-1742

Nurdin, B. V. (2020). Covid 19 Dan Filantropi. Lampung Post.

Putri, I. F., \& Hidayat, H. (2011). Analisis Persepsi Modal Sosial Dan Hubungannya Dengan Eksistensi Kelompok Tani: Kasus Pada
Kelompok Tani Wanita "Sri Sejati 2",. Wacana.

Rahmadi, P. Z., \& Santoso, B. (2016). Modal Sosial Petani Sawah Berlahan Sempit Dalam Pemenuhan Nafkah Rumah Tangga. Jurnal Analisa Sosiologi.

Ramdhani, H., Nulhaqim, S. A., \& Fedryansyah, M. (2015). Peningkatan Kesejahteraan Petani Dengan Penguatan Kelompok Tani. Prosiding Penelitian Dan Pengabdian Kepada Masyarakat.

Https://Doi.Org/10.24198/Jppm.V2i 3.13593

Schwitter, N. (2020). Social Capital In Retirement Villages: A Literature Review. In Ageing And Society. Https://Doi.Org/10.1017/S0144686x 20001610

Sidik, F. (2015). Menggali Potensi Lokal Mewujudkan Kemandirian Desa. Jkap (Jurnal Kebijakan Dan Administrasi Publik).

Https://Doi.Org/10.22146/Jkap.7962

Suhaeni, E. (2019). Pendidikan Sebagai Kapital Sosial (Sebuah Tinjauan Sosiologis). Islamika. Https://Doi.Org/10.33592/Islamika. V13i1.154

Sulastriyono, \& Saputra, J. (2020). A Study Of Supply Chain Management Aspects Of Village Owned Enterprises In Indonesia. International Journal of Supply Chain Management, 9(3), 12211229.

Wati, D. R. (2015). Akses Kredit Mikro Pada Petani Padi Organik Di Kabupaten Bogor. Agribusiness Journal. Https://Doi.Org/10.15408/Aj.V9i2.5 286

Widodo, S. (2011). Strategies Of Sustainable Livelihood For Poor Household In Coastal Area. Makara, Sosial Humaniora.

Xu, D., Deng, X., Guo, S., \& Liu, S. (2019). Sensitivity Of Livelihood Strategy To Livelihood Capital: An Empirical Investigation Using Nationally Representative Survey Data From Rural China. Social Indicators Research, 144(1), 
Https:/ / Doi.Org/10.1007/S11205-

018-2037-6

Yahya, T., \& Yahya, S. (2020). Social Characteristics And Differences Of Urban And Rural Communities. Journal La Sociale, 1(5), 24-27. Https://Doi.Org/10.37899/Journal-

La-Sociale.V1i5.204 